\title{
INTRODUCING ORGANISATIONAL HERITAGE: LINKING CORPORATE HERITAGE, ORGANISATIONAL IDENTITY, AND ORGANISATIONAL MEMORY
}

\author{
THIS IS A PRE-PUBLICATION VERSION OF ARTICLE TO BE PUBLISHED IN \\ THE JOURNAL OF BRAND MANAGEMENT (2005) Vol 22 No 5/6 (to be confirmed) \\ For reference purposes kindly refer to the information provided by the above journal once \\ the article has been published
}

\author{
John M.T. Balmer \\ Brunel Business School \\ Brunel University London UK \\ Mario Burghausen \\ Essex University Colchester UK
}

\begin{abstract}
About the authors:
John M.T. Balmer is Professor of Corporate Marketing at Brunel University Business School London; quondam Professor of Corporate Brand/Identity Management at Bradford University School of Management and Chairman of the Board of Senior Consultant Editors of the Journal of Brand Management. Took his PhD at Strathclyde University, Scotland in 1996 and within 3 years was elected Professor of Corporate Identity at Bradford University where he was subsequently conferred the title of Professor of Corporate Brand/Identity Management. In 2007 he was appointed Professor of Corporate Marketing at Brunel University London. All three Professorial appointments are understood to be the first appointments of their kind. He is credited with writing the first articles on corporate brands (1995) and corporate marketing (1998) and codeveloped the corporate heritage brand notion in the late 1990 s and went on to formally introduce the corporate heritage identity, corporate heritage marketing notions. His articles have been published in leading journals including the California Management Review, European Journal of Marketing, British Journal of Management, Long Range Planning, Journal of Business Research, Industrial Marketing Management, etc.
\end{abstract}

Mario Burghausen is Lecturer in Marketing at Essex Business School, University of Essex in Colchester, UK. He has extensive industry experience having worked for Allianz of Germany (Insurance), amongst others, in different managerial and non-managerial roles prior to his move into academia. He holds a PhD (Brunel University, London) and his general research interests are within the nascent fields of corporate marketing and corporate heritage scholarship (and related areas). He has published articles in the Journal of Business Research, European Journal of Marketing and Corporate Communications: An International Journal. 


\begin{abstract}
In this article we formally introduce and explicate the organisational heritage notion. The authors conclude organisational heritage can be designated in three broad ways as: (1) organisational heritage identity as the perceived and reminisced omni-temporal traits - both formal/normative and utilitarian/societal - of organisational members' work organisation; (2) organisational heritage identification as organisational members' identification/selfcategorisation vis-à-vis these perceived and reminisced omni-temporal traits of their work organisation, and (3) organisational heritage cultural identification as organisational members' multi-generational identification/self-categorisation vis-à-vis the perceived and reminisced omni-temporal traits of their work organisation's corporate culture. To date, advances in heritage studies at the institutional-level have primarily taken place within the broad corporate marketing paradigm. However, we are mindful of developments in the organisational memory field and the need to address and engage with organisational behaviour/management scholarship in the broad organisational identity domain. The realisation that there is a distinct genus of corporate heritage institution (corporate heritage identity) and brand (corporate heritage brand) represents a seismic shift in how scholars theorise about heritage institutions and corporate heritage brands and how the aforementioned are managed. In the development of a field concept introduction and explanation is a key means through which an area can progress and the explicit aim of this article is to achieve the aforementioned by our elucidation of the organisational heritage notion. We argue the literatures on corporate heritage identity, organisational identity, and organisational memory are of assistance in appreciating the saliency of organisational heritage. As such, by building on embryonic scholarship in the corporate heritage this article aims to explicate the nature and significance of organisational heritage. The implications of organisational heritage for corporate heritage brands are also delineated.
\end{abstract}

\title{
Correspondence:
}

\section{John M.T. Balmer,}

Brunel Business School

Brunel University London, UK

Mario Burghausen

University of Essex

Colchester, UK 


\section{INTRODUCTION}

This article has the explicit objective in making a significant advance in corporate heritage studies by formally introducing the organisational heritage notion as a significant branch area of the above. As such we formally introduce the organisational heritage concept. The organisational heritage concept, for us, is important since it may represent the progenitor for a parallel area of scholarship vis-à-vis corporate heritage studies namely, organisational heritage studies.

Arguably, by providing a formal introduction and explication (explinandum) of the organisational heritage notion, there is the potential to meaningfully expand the theoretical and instrumental significance of the broad corporate heritage domain. Our rationale for this is straightforward. For us, the corporate heritage notion is of especially relevance for the established and mature field relating to organisational identity and organisational identification. Yet, to date, organisational behaviourists and management scholars (who for the main focus on organisational identity and organisational identification) have not accorded heritage significance.

\section{Significance of organisational heritage for corporate marketing, corporate brand management, management and organisational behaviour studies.}

Since the organisational heritage concept focuses on organisational members in particular, the formal institution of the organisational heritage notion is not only propitious but of broad pertinence too. Thus, the concept is predicted to be of saliency not only to management and organisational behaviour scholars. Moreover, the concept is highly significant for corporate marketing and corporate brand scholars and managers too. Why is this so?

This is because both the corporate marketing and the closely-related corporate brand fields both stress the importance on organisational members (employees etc.) and their conceptualisations of and identification with an organisation's corporate identity (or its corporate brand).

In formally introducing and delineating the organisational heritage notion we specifically draw on the corporate heritage, organisational identity and organisational memory 
literatures. For us, all three perspectives substantially inform our understanding of the organisational heritage construct.

\section{Heralding the organisational heritage construct}

Taking an explicit theory-building perspective, to date, most research on the corporate heritage domain has been informed by corporate identity and corporate brand scholarship. However, as corporate marketing scholars we realise organisational behaviour and management perspectives represent a neglected dimension of the heritage phenomenon. To date, heritage has not yet featured prominently as a distinctive concept within the organisational behaviour and management fields. For this reason there is a need for an explanandum (identifying the phenomenon requiring explanation) as well as an explanans (the nature of the phenomenon).

Whilst this article formally introduces the organisation heritage notion we note the tentative - albeit preliminary - moves, which in their modest ways have heralded our examination of organisational heritage as a distinct construct. For example, the corporate heritage literature has presaged the focus of this article by noting the potential significance of what has been labelled "corporate heritage social identity theory" (Balmer 2013, p. 321) and by providing an initial definition of corporate heritage culture as:

"The perennial sense of who we are on the part of successive generations of organisational members and, where applicable, owners (family-owned businesses for example)" (Balmer, 2013. p. 318).

The literature has also provided - as an aside - a short embryonic voicing of organisational heritage and attendant concepts:

"The significance of heritage to organisational members of the broad corporate heritage notion opens extant corporate marketing scholarship on the territory to scholars within the organisational behaviour field. As such, the extant concepts of organisational identity, organisational identification can be adapted within a corporate heritage context viz: organisational heritage/organisational heritage identities and organisational heritage identification". (Balmer and Chen 2015, p.202)

The substantive and progressive treatment of the organisational heritage notion as delineated in our article clearly represents a significant advance on the embryonic and predicted contributions detailed above. 


\section{The envisioned importance of organisational heritage}

We argue the theoretical notion of organisational heritage provides an additional, and highly salient, perspective vis-à-vis corporate heritage scholarship and practice but also to research and scholarship in the organisational behaviour and management research domains too. This is because heritage conceptualised via the lens of what we refer to as organisational heritage stresses its pertinence for organisational identity and identification within an organisation, which is in the traditional purview of management and organisation studies. In addition, and to repeat and elaborate on an earlier point, this notion has important implications for extant corporate marketing perspectives (e.g., the identity-based view of the firm and corporate brand orientation, see Balmer 2008, 2013b and the culture dimension of the corporate marketing mix, see Balmer 2011a) and also for corporate brand scholarship and practice (e.g., the notion of internal brand building, see de Chernatony and Vallaster, 2006; internal brand commitment and employee identification, see Stuart, 2002, 2012; Burmann and Zeplin, 2005 and corporate brand orientation, see: Balmer 2013b).

To us, both corporate heritage and organisational heritage are foundational constructs for the heritage field in institutional contexts. Both concepts can be discriminated from the corporate identity and organisational identity notions as well as from various past-related concepts per se (e.g., history, memory; see Burghausen and Balmer 2014b). This is because they are both concerned not only with the past, and the present but concurrently with the prospective future too: omni-temporality is one of the defining precepts of heritage within the field (Balmer et al 2006, 2013: Urde et al 2007).

\section{Explaining organisational heritage: propitious and expedient development}

It is our hope our formal introduction and scrutiny of the organisational heritage notion is propitious particularly in terms of timing but also expedient in speaking to scholars and managers beyond corporate branding and marketing. In addition, we believe our reflections will be opportune and of utility to our colleagues within management and organisational behaviour. 


\section{6}

Both of us come for the corporate marketing tradition where cross-disciplinary insights and multiple theoretical viewpoints are valued and welcome. Yet, our marketing provenance also demands that we consider the instrumental utility of our research and scholarship. As such, we hope our work speaks to scholars and managers too; in bridging what Balmer sometimes prosaically calls in his lectures: "the college cloister - corporate headquarter divide".

In sponsoring the organisational heritage construct our motivations are ambassadorial rather than imperial. Moreover, we strive to achieve a championing rather than hectoring tone in elucidating the organisational heritage notion.

We hope our references to scholarship in parallel management domains will have the effect of bringing their work to the attention of a wider audience within the marketing and branding field. Perhaps, too, there will be some reciprocation and acknowledgment from management and organisation scholars in the other direction? For us, contemplating an area through a single lens can lead to penetrating insights but might also, alas, at times prevent critical variety and perspective.

\section{Structure of the article}

In formally introducing and advancing the organisational heritage notion, this article continues by:

(2) Contextualising the domain and by examining three pivotal literatures which together inform the organisational heritage construct;

(3) Explaining and examining the foundational literatures relating to (3.1) corporate heritage, (3.2) organisational identity, and (3.3) organisational memory. Their import for organisational heritage is outlined.

The aforementioned reflections facilitate:

(4) Defining organisational identity as a distinct construct in terms of organisational heritage identity; organisational heritage identification, and organisational heritage culture identification.

(5) Articulating the significance of the organisational heritage construct including its general instrumental import and delineating its relevance for the management of corporate heritage brands and future research directions.

(6) Concluding remarks. 
Figure 1: Structure of Article
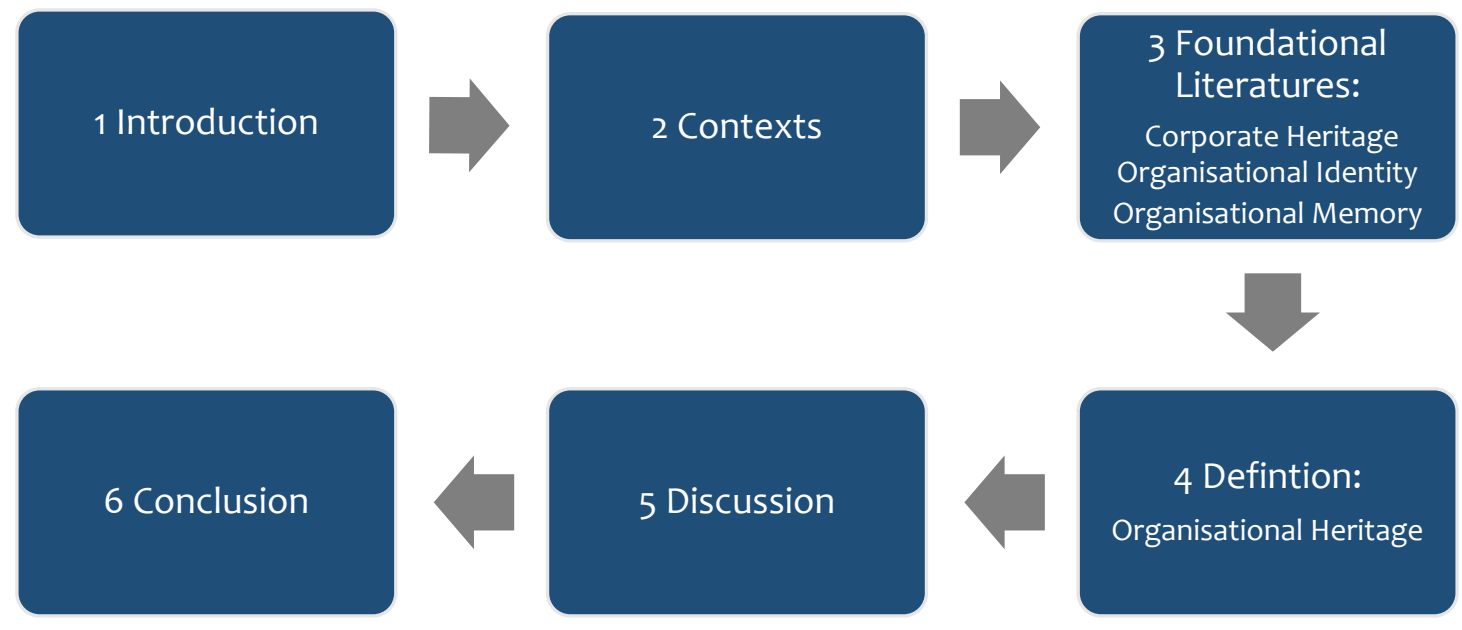

\section{CONTEXTS}

\section{Reflections on the past and temporality in corporate marketing and management}

Problems of temporality and, more specifically the past and its interaction with the present, have long captivated academia and, earlier still of course, philosophers (viz: Aristotle, St. Augustine, Duns Scotus, Parmenides, Plato etc.) and more recently also gained in instrumental relevance for managers (e.g., using historical references for corporate branding and corporate communication). Not surprisingly, therefore, both concerns have emerged as fertile areas of scholarship within marketing and management studies.

Arguably, the dominant perspective in corporate marketing relates to corporate heritage whilst in management/organisation studies the primary focus is on the notion of organisational memory. However, despite their obvious efficacy in revealing attributes and impacts of the past in the institutional present, they both still represent underresearched fields. 


\section{8}

From the outset, we acknowledge the enduring significance of the business history field: an area which was greatly popularised by the legendary Alfred Chandler (1962) and which has given rise to authoritative journals on the area such as the Journal of Business History.

However, history and heritage in marketing and organisational contexts, whilst representing related areas, are nevertheless distinct as conceptual categories, as empirical phenomena and as fields of scholarly inquiry. In conceptual and empirical terms, all organisations can be said to 'have a history' of sort but only a smaller number have a meaningful and valuable corporate heritage (Urde et al. 2007). This can be viewed as the selectively appropriated and valorised past in the present and for the future vis-à-vis internal and external stakeholders (Burghausen and Balmer 2014b). As such, there is conceptual and substantive difference between whether the past is articulated in the present as history or heritage (or as any other mode of referring the corporate/organisational past such as corporate/organisational memory, see Burghausen and Balmer 2014b).

Further, as field of inquiry business history very much focuses on understanding and explaining the institutional past by providing a retrospective 'factual' account of a sequence of intersecting social, political and economic events that may also help to explain the present (Jones and Zeitlin, 2009). Yet, marketing and management scholarship is more interested in the symbolic and instrumental relevance of 'the past' as an enabling or constraining constitutive element or contingent factor in the present and for the future of organisations (see Balmer and Burghausen, 2015).

The above being noted, it is also clear that recent developments in corporate marketing (e.g., Burghausen and Balmer 2014a, 2015; Balmer and Chen 2015) and in management (e.g., Anteby and Molnar, 2012; Decker, 2014) show that through a broad scrutiny of and engagement with the past in the present important insights can transpire. Editorial box 1 explores some aspects of this development in more detail.

INSERT EDITORIAL BOX 1 HERE 


\section{Corporate marketing and management: Differences in temporal foci}

Nonetheless, there are some notable differences in terms of temporal foci. Management scholars tend to focus on a dual temporal perspectives, either by focussing on the past and present through retrospective sense-making, for instance (Weick 1995), or by stressing the present-future link via, for example, prospective sense-giving (Gioia and Thomas, 1996). In contrast, corporate marketing/corporate heritage scholars usually adopt an Omni-temporal perspective (focussing on the past, present and prospective future concurrently) which is exemplified by, for example, the notion of custodial responsibilities of management vis-à-vis past, present and future stakeholders derived from a corporate marketing logic (Balmer and Greyser 2006; Balmer 2011a heritage brands and identities (Balmer 2011b; Balmer 2013a).

In light of the aforementioned, we are mindful of the significant contributions made by cornerstone articles published in the Journal of Brand Management (JBM) on corporate heritage management (Balmer et al. 2006; Urde et al. 2007; Balmer 2011a) and subsequent empirical work related to the above in the JBM (Balmer and Chen 2015; Schroeder et al. 2015; Cooper et al. 2015; Bargenda 2015; Rindell et al. 2015).

\section{Corporate versus organisational perspectives}

Novices of the broad field need to be appraised that distinct terminologies tend to characterise and define different disciplinary perspectives. Thus, in corporate marketing the word “corporate" prevails vis-à-vis key constructs (via: corporate brand, corporate identity, corporate image, corporate reputation, corporate culture and corporate communication). In contrast the word "organisational” predominates in research undertaken by organisational behaviourists and management scholars (organisational identity, organisational identification, organisational image, organisational communication etc.). Curiously, organisational behaviourists refer to the corporate brand rather than to the 'organisational brand' which seems - to some corporate marketing scholars - somewhat inconsistent if not illogical. It also can cause considerable confusion.

As a general rule "corporate" relates to an understanding of a construct from strategic, corporate marketing, and stakeholder perspectives and which refers to all types of 'incorporated' entities (de jure or de facto) that are identifiable as discrete commercial, 
public and/or civic entities (not only corporations but also municipalities, charities, or associations, for example): see the identity-based view of the firm perspective for a discussion of the above (Balmer, 2008).

This understanding is informed by a perspective which views organisations as having distinct and substantive identities imbued with "identifiable" traits (which can be ideational as much as material traits). As such, organisations are seen as independent institutional actors with their own identity requirements and particularities that are qualitatively different from the identities of individuals or groups of people (albeit interdependent with those).

In contrast “organisational”, typically, denotes an understanding of an organisation's identity as being predicated solely on the individual and shared meanings of organisational member vis-à-vis the organisation. This primarily internal perspective views perceptions, attributions and interpretations by organisational members as being constitutive for an organisation's identity (and often for the organisation per se) that manifest through individual and group identities within an organisation.

\section{The corporate and organisational relationship}

The formal introduction of the organisational heritage by corporate marketing academics might, at first sight, seem odd. However, this is simply a rehearsal of what has already taken place in business identity scholarship. For instance, as noted by Hatch and Schultz (2004, p.2) - prominent scholars in the organisational behaviour field - the foundational work on (business) identity was undertaken by marketing and communications scholars (and practitioners) and these insights presaged the equally important but subsequent work undertaken by scholars from management and organisational behaviour. Moreover, early scholarship in the corporate identity field also already heralded the later rise of the organisational identity/organisational identification notions as can clearly be gleaned, for example, from the work of Tagiuri (1982) at Harvard Business School; Larçon and Reitter in France (1979); or the work of Wiedmann and his German colleagues at Mannheim University in the 1980s (Jugel et al. 1987; Wiedmann 1988). 
This early engagement with the problem of business identities is not surprising in as much as marketing and strategy scholars tend to derive their conceptual insights in close alignment with the emerging managerial problems of the day. As such, following a venerable tradition, marketing scholars de facto have been engaged in explaining a prevalent and important phenomenon at that. Perhaps, unsurprisingly, these early scholarly discussions of business identities are complemented by the seminal contributions of corporate identity consultants such as Olins $(1978,1989)$ or Birkigt and Stadler (1980), who also already stressed the behavioural elements and internal effects of an organisation's identity (in addition to identity manifestations through design and communication). For a discussion of the contribution of Olins to identity studies see: Balmer (2014; 2015).

In a similar vein, therefore, the concept of corporate heritage has prefigured the organisational heritage notion which we introduce and promulgate here.

However, the marketing and management literatures have tended to follow distinct lines of development and thus do largely exist in isolation from each other. One problem has been the reluctance of many non-marketing scholars to recognise and engage with the scholarly work undertaken within marketing and its established provenance in management practice. Even Albert and Whetten (1985) - who are usually credited with the formal introduction of the organisational identity notion - studiously avoid all mention of corporate identity (which was by then a well-established management practice) in their otherwise magisterial chapter on organisational identity. This being noted, today, both fields have significantly contributed to our discernment of the broad identity domain as cross-disciplinary literature reviews attest (Cornelissen et al 2007: He and Balmer 2007; Balmer 2008; Perez and del Bosque 2014).

To us, both perspectives separately are necessary but are, of course, limited for understanding the complexity of identity phenomena vis-à-vis organisations. As such, a multi-disciplinary approach is efficacious (Balmer 1995; 2001b; He and Balmer 2007: Balmer 2008). 


\section{ORGANISATIONAL HERITAGE: THE FOUNDATIONAL LITERATURES}

Three main literatures - on corporate heritage, organisational identity/identification and organisational memory - are salient in explaining the organisational heritage notion and its characteristics. Why is this so?

First, the corporate heritage canon has establishes that a distinct category of organisation/ corporate brand exists (a corporate heritage brand/corporate heritage identity). As such, this literature establishes the existence, significance and prevalence of corporate heritage as a phenomenon. Arguably, therefore, it provides the basis - and rationale - for the formal introduction of the organisational heritage theoretical notion. Within this nascent literature the nature, importance and attractiveness of corporate heritage brands/corporate heritage identities are delineated. This ubiquity throws light on the nature, emergence and importance of corporate heritage for institutions and explains the significance of omni-temporality, tri-generational inheritance and affinity to a corporate heritage entity; among other salient corporate heritage traits.

Second, the organisational identity/identification canon details the importance of meanings and interpretations by organisational members for comprehending an institution's key identity traits and highlights the significance of their identification with them or through them. As such, the above insights from can be marshalled so that it applies and is meaningful to our understanding of corporate heritage institutions. By the same token, the corporate heritage notion is of particular relevance in comprehending organisational identity as a temporal phenomenon as well.

Third, the nascent organisational memory canon explores how institutions and employees make sense of their institution's past in contemporary contexts through processes of remembering and forgetting. As such, the notion employees' cognitions are shaped by the past can also be marshalled so that it applies and is meaningful for our understanding of corporate heritage institutions.

Elaborating the above, the corporate heritage field delineates the existence, characteristics and attractiveness of corporate heritage identities/corporate heritage brands as significant institutional and societal phenomena. These insights provide a spur for considering the aforementioned via the organisational identity/identification and organisational memory fields. As such, marshalling the organisational 
identity/identification and organisational memory canons has the potential to enhance our comprehension of the phenomenon. Why is this so?

This is because the phenomenon can be more fully comprehended and advanced by considering organisational members' cognitions of corporate heritage traits along with issues of their identification with heritage organisations and corporate heritage brands by taking account of issues relating to organisational memory.

To repeat, these literatures - corporate heritage, organisational identity/identification and organisational memory - not only provide the bases for our explication of the organisational heritage construct (see figure 2) but also, usefully, inform the structure for the remainder of this section.

Figure 2: Organisational Heritage - Foundational Literatures

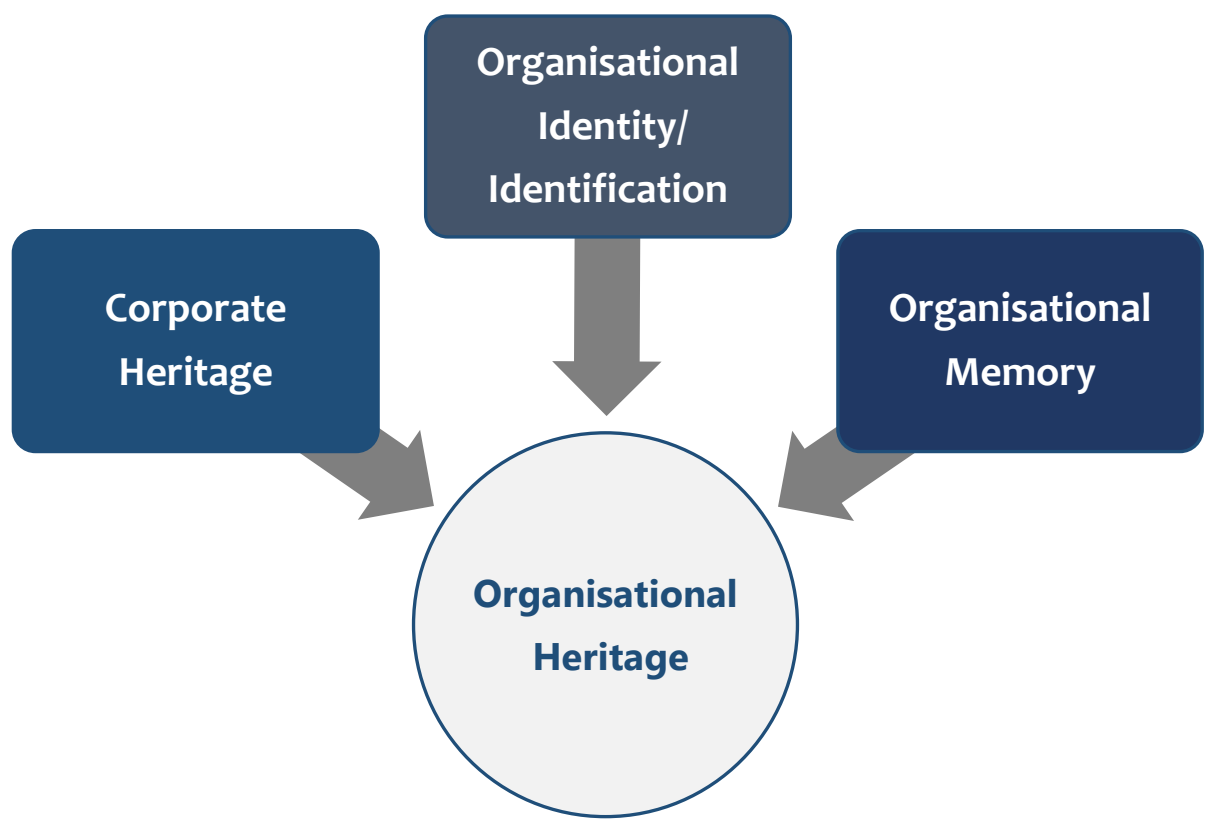

\section{Corporate heritage (foundational literature)}

The corporate heritage (corporate heritage brand/corporate heritage identity) canon is germane to our discussion of the organisational heritage construct since it helps to delineate core dimensions. 
Dating back to the mid-2000's, the corporate heritage notion respectively refers either to a distinct genus of corporate brand - 'corporate heritage brand' (Balmer et al. 2006; Urde et al.2007) - or to a distinct type of corporate identity - 'corporate heritage identity' (Balmer 2011b; Balmer 2011c; Balmer, 2013a; Burghausen and Balmer 2014a; 2015). Initially, corporate heritage scholarship very much focused on instrumental concerns (Balmer et al. 2006; Urde et al. 2007; Blombäck and Brunninge 2009; Balmer 2011a, 2011b, 2013) and a good deal of this literature focussed on the corporate heritage brand construct. It is the nascent literature on corporate heritage identity (Balmer 2011; Burghausen and Balmer, 2014a; 2015) and the broader conceptual discussions of possible links between various past-related concepts (Balmer 2011C; Burghausen and Balmer 2014b) which are of pertinence to our discussion of organisational heritage. Why is this so?

This is because it naturally falls within the broad business identity domain (Balmer, 2001) and for the reason that corporate identities underpin corporate brands (Balmer, 1995; 2012); with the same logic applied to corporate heritage brands too (Urde et al. 2007; Balmer 2011a). At the same time, the identity-based view of the firm which underpins corporate marketing links corporate identity to issues of organisational identification (Balmer, 2008). Finally, the repertories of the corporate past perspective (Burghausen and Balmer 2014b) also includes the notion of corporate memory as being delineated from but also linked to corporate heritage (amongst other concepts), which provides a conceptual bridge to the organisational memory literature.

First recognised by Balmer et al. (2006) and more explicitly discussed by Balmer (2011b) corporate heritage institutions were conceptualised as having certain perennial identity traits. Balmer (2011b) explained why corporate heritage identities were highly meaningful by:

- $\quad$ arguing heritage institutions were invested with "institurional or multiple role identities" which were associated not merely with the organisation's activities but were meaningfully linked to other identities linked with people and places, cultures etc.);

- noting how corporate heritage institutions conferred identity to peoples, places, communities and cultures;

- introducing the theoretical notion of relative invariance where although heritage organisations appear to be invariant they are likely in fact to be variant;

- suggesting bi-lateral trust was important as was dependent on authenticity on the part of the corporate heritage institution and affinity on the part of customers and other stakeholders. 
In defining a corporate heritage identity Balmer (2011b, p.1385) stated:

"Corporate heritage identities should be viewed as a distinct identity type. Corporate heritage identities refer to those institution al traits which have remained meaningful and invariant over the passage of time and, as such, a corporate heritage identity viewed as being part of the past, present and future. This said, the meanings attached to particular facets of an institution's identity can vary with the passage of time. Heritage identity traits can include corporate competencies, cultures, philosophies, activities, markets and groups etc. and may find, in addition, expression in distinctive visual identities, architecture and service offerings."

It was subsequently maintained that corporate heritage identities are informed by key traits and core management imperatives (Balmer, 2013). These encompass:

1. Omni-temporality (subsisting in temporal strata of the past, present and a prospective future)

2. institutional trait consistency (the continuity of meaningful organisational traitsand this can include corporate culture)

3. tri-generational hereditary (the organisation has to have been in existence, and meaningful, for a minimum of three generations)

4. augmented role identities (corporate heritage institutions are infused with multiple role identities including territorial, cultural, social and ancestral identitythis reinforced the institutional role identity notion mentioned earlier)

5. ceaseless multigenerational stakeholder utility (demonstrably salient for consecutive generations of stakeholders)

6. unremitting management tenacity (assiduous management of corporate heritage institutions)

These are shown in diagrammatic form in figure 3.

Figure 3: Corporate heritage traits and core management imperatives (Balmer 2013)

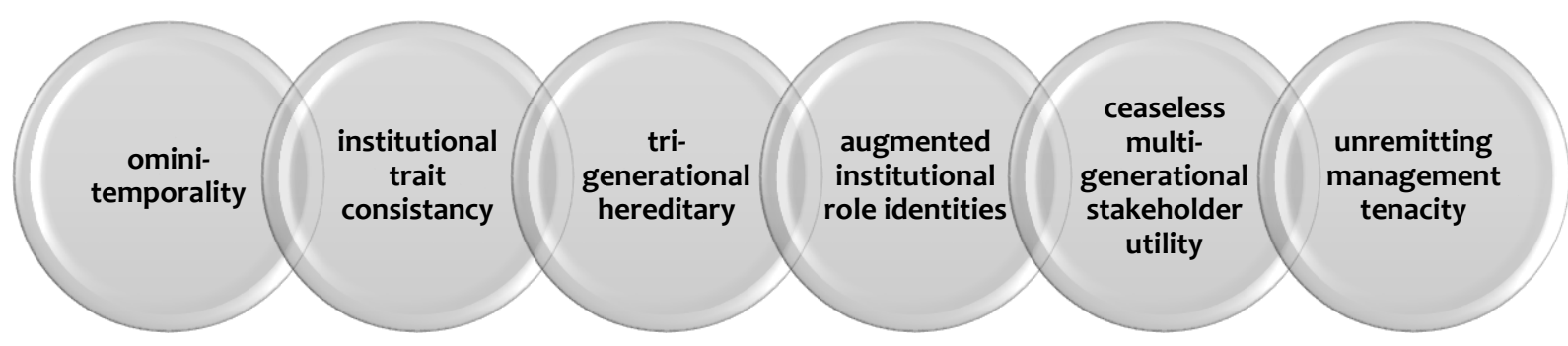


Whilst many of the above traits are important, the notion that heritage institutions are invested with meaningful institutional role identities (Balmer 2011b) or augmented role identities (Balmer, 2013a) has been stressed. As such, heritage institutions are an amalgam of corporate "formal/normative" and "social/utilitarian" identities. As such, heritage institutions, with the passage of time acquire new identities and this accords heritage institutions augmented significance and relevance. For instance, heritage organisations can become associated with places, cultures, and peoples (Balmer, 2011b). See Figure 4 below.

Figure 4: Balmer's (2011b; 2013a) Augmented Institutional Role Identity Notion

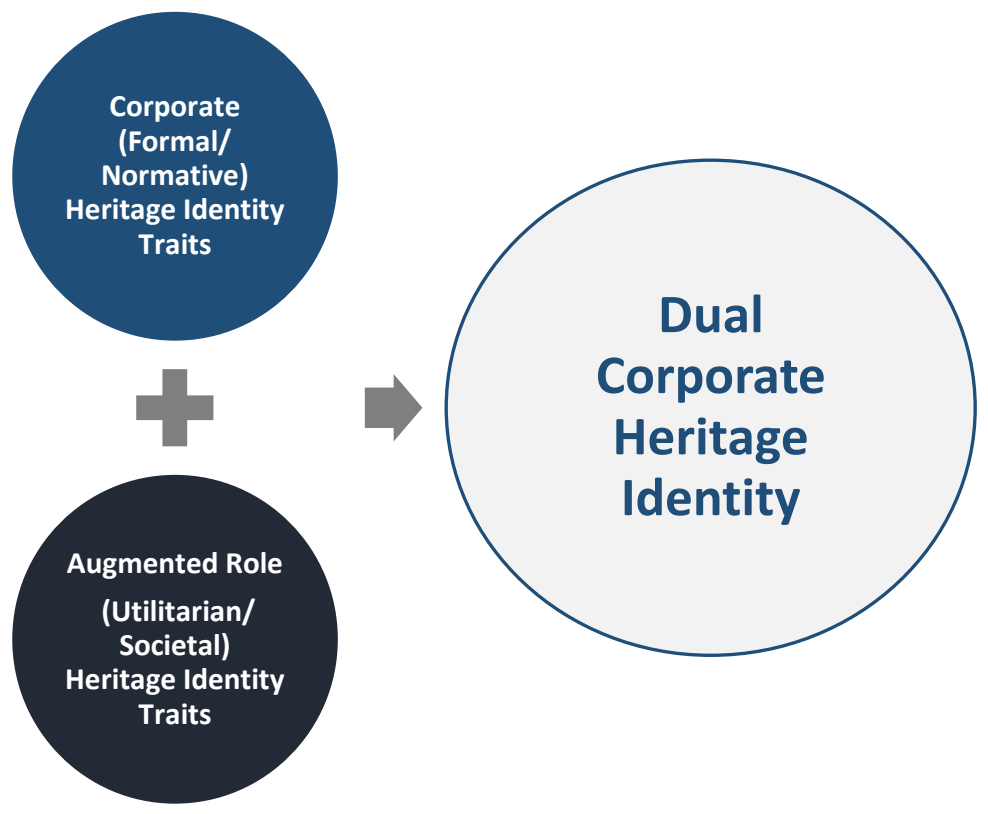

The extant corporate heritage literature reveals that corporate heritage brands and corporate heritage identities constitute a specific type of brand/identity with specific characteristics, management requirements and impacts vis-à-vis stakeholders. Both are fundamentally predicated on corporate heritage as a concept and phenomenon. Consequently, the corporate heritage literature has delineated corporate heritage as a distinct foundational concept (Balmer 2011b; 2013; Burghausen and Balmer, 2014b). As such, it is different from the past or history per se (Urde et al 2007; Balmer 2011b; Burghausen and Balmer 2014b) and which refers to: 
"... all the traits and aspects of an organisation that link its past, present, and future in a meaningful and relevant way. Thus, it refers to some aspect of an organisation's past that is still deemed by current internal and/or external stakeholders to be relevant and meaningful for contemporary concerns and purposes but concurrently perceived as worth to be maintained and nurtured for future generations; it is the selectively appropriated and valorised past of a company or 'all that is (still) relevant' in the light of contemporary concerns and purposes" (Burghausen and Balmer 2014b, p. 394-95).

Recently, and based on the understanding of corporate heritage articulated above, emphasis has been accorded to processes of appropriation and valorisation of the past vis-à-vis corporate heritage and the activities of various organisational constituents.

This includes: managerial cognition, self-understanding and enactment (Burghausen and Balmer 2014a, 2015); the cognitive, behavioural and experiential effects of heritage claims on consumers (Wiedmann et al, 2011a, 2011b; Hudson, 2011; Hudson and Balmer, 2013); corporate heritage image construction by customers and other stakeholders vis-à-vis an institution's corporate heritage claims (Rindell et al 2015) and consumer attractiveness towards corporate heritage (Balmer and Chen 2015) and the significance of collective memory in managing a corporate heritage brand (Balmer 2009).

The recognition that corporate heritage identities and corporate heritage brands represent a distinct category of corporate identity and corporate brand has done much to explain the existence, importance, and characteristics of the broad corporate heritage phenomenon. In addition the value or the assigning of value to corporate heritage/corporate heritage institutions by customers, clearly, can be a parallel concern for organisational members (e.g., how and why do they valorise certain aspects of the past into heritage and not others?). In addition, just as customers' and other external stakeholders' understanding of corporate heritage can be of strategic and behavioural importance for organisations a parallel case can be made for organisational members too. As such, corporate heritage provides a clear link and foundation for the literatures on organisational identity and organisational memory, and moreover our explanation/s of the organisation heritage notion herein. 


\section{Corporate heritage: ostensible linkages to organisational identity}

In summary, evident links to the organisational heritage notion from the corporate heritage domain can be recognised as follows:

- core corporate heritage traits articulate a core precepts of corporate heritage and this is significant in terms of addressing issues of organisational identity

- corporate culture is regarded as a corporate heritage trait

- the multiple generation perspective of corporate heritage is also of saliency vis-à$v i s$ to organisational members (in terms of conceptualisation of organisational heritage and identification with a heritage entity)

- corporate heritage institutions confer identity to peoples, places, communities and culture: this is significant in recognising that individual and groups - and in particular organisational members - can identify with and be defined by corporate heritage identities

- this theoretical notion of institutional/ augmented role identity theoretical perspective (Balmer 2011b; 2013) explains that heritage institutions are imbued with hybrid identities which relate to the organisation and, significantly, to territories, peoples, culture and other significant identities

- the notion of bi-lateral trust (dependent on authenticity on the part of corporate heritage institutions and affinity on the part of stakeholders - especially organisational members)

- the process of selective appropriation and valorisation of the past into heritage by various stakeholders has been recognised: this is also of pertinence to organisational members

Just as there are a variety of approaches or "school-of-thought" vis-à-vis corporate identity (Balmer 1995; He and Balmer 2007; Balmer 2008), the same is true of organisational identity as noted by Hatch and Schultz (2004, pp. 1-6). These perspectives found within the broad business identity can also be meaningful in characterising the "school- of-thought" in the organisational heritage domain as identified, articulated, and advanced in our article.

\section{Organisational identity/identification (foundational literature)}

The organisational identity construct was formally introduced by Albert and Whetten (1985). Their cornerstone conceptual article has greatly influenced a generation of scholars in the management and organisational behaviour fields (Ashforth and Mael 1989; Dutton and Dukerich 1991; Dutton et al. 1994; see Whetten and Godfrey 1998; Hatch and 
Schultz 2004). Focussing on organisational members (rather than customers and other stakeholders; which largely characterises the corporate identity domain), the organisational identity notion (for management and organisational behaviour scholars) is viewed as a socially-constructed phenomenon with two main perspectives dominating the literature: (i) organisational members cognitions of institutional traits and (ii) their self-definition vis-à-vis their work organisation.

\section{Organisational member's cognitions of an institution's traits (first organisational identity perspective)}

The first perspective specifically refers to organisational members' cognitions and shared meanings ("sense-making") in relation to the organisation and its defining traits which are perceived/claimed by them to be central, distinctive and enduring (Albert and Whetten 1985).

For instance, according to Albert and Whetten (1985), organisational identity relates to organisational members understanding of their work and, in particular focuses on key questions such as "Who are we?" and "What kind of business are we in" or "What do we want to be?"

Whilst Albert and Whetten's criterion has been highly influential and pervasive (viz: claimed centrality, distinctiveness, and enduringness) scholars have accorded less importance to the distinctiveness criterion whilst others have questioned the enduringness criterion. Also, most organisational behaviourists/management scholars are seemingly unaware of the earlier-analogous-and highly pertinent corporate identity criterion developed by Larçon and Reitter (1979. 1984).

In terms of appraising the impact of the above, it would appear the centrality criterion suggested by Albert and Whetten (1985) - as deeply rooted or widely shared amongst members, for instance - has been widely discussed within the organisational identity canon. In contrast, the distinctiveness criterion has received little attention (Corley et al. 2006). As an aside, distinctiveness is of particular interest in both corporate marketing and corporate branding contexts. This is because it can be viewed as of a parallel dimension of the key marketing notion of differentiation through positioning (Ries and Trout, 1981) and, as such, is of relevance for corporate branding and marketing in general. Of course, positioning was found to be a key dimension of the first corporate marketing 


\section{0}

mix (Balmer 1998). It should be noted that the main thrust of the organisational identity focuses on individual identification - and its effects - vis-à-vis their group membership or role within the organisation (Ashforth et al. 2008). For some organisational behaviourists/management scholars, the enduring criterion of Albert and Whetten (1985) has been questioned = and subject to considerable debate- within the organisational identity field (Gioia, et al 2000; Whetten and Godfrey, 1998).

Albert and Whetten's (1985) perspective shows some parallels and interesting similarities to the, less-widely referred to, corporate marketing notion of corporate identity as we indicated above. As such, the holistic (rather than narrow graphic design) corporate identity perspective is conceptualised as a particular pattern of ideational and material traits over time that give an entity specificity, coherence and stability vis-à-vis stakeholders (Larçon and Reitter 1979, 1984; see Moingeon and Ramanantsoa 1997; Balmer 2008). It is the unique combination of such traits which reveal the Gestalt of the organisation to organisational members, customers and other stakeholders (Balmer and Greyser, 2003).

As an important aside, Albert and Whetten (1985) also noted that some organisations are invested with formal and social identities (normative and utilitarian). This reflection on hybrid identities has been shown to be applicable to corporate heritage entities following on the institutional/ augmented role identity theoretical perspective of (Balmer 2011b; 2013). Balmer and Chen (2105) found that Tong Ren Tang (TRT), as a corporate heritage entity, had a dual identity as a formal and social identity with TRT having multifarious formal and social organisation purposes. Balmer's study of the BBC also revealed the saliency of multiple normative and utilitarian identities (see: Balmer 1996; Balmer and Wilson, 1998).

\section{Organisational members' identification with an institution (second organisational identity perspective)}

A second understanding of organisational identity relates to how organisational members define themselves as individuals in the context of their work organisation and vis-à-vis other organisations (Ashforth and Mael 1989). This perspective is informed by a prominent sociological theory viz: social identity/self-categorisation theory (Turner, 1975; 
Tajfel, 1982) which was adapted by Ashforth and Mael (1989) so that it had an organisational applicability vis-à-vis organisational members.

The scholarship of Ashforth and Mael (1989) is noteworthy since they explained how organisational members often define themselves in terms of their work organisation. In other words - according to this second perspective of organisational identityorganisational identity is concerned with organisational identification. In other words, organisational identity equates to how an individuals can characterise themselves in terms of their work organisation and relates to the perceived 'oneness' of an individual with the organisation as a group of people (Ashforth and Mael 1989, p. 34).

Interestingly, Ashforth and Mael (1989, p.26) also noted the significance of culture vis-àvis identification:

"... social identification enables the individual to conceive of, and feel loyal to, an organisation or corporate culture."

There are certain parallels with the above and the work of Balmer (2008) in the corporate identity field made a distinction between identification with an organisation and identification with a corporate culture. The work of Podnar, et al. (2011) is also significant in this regard too.

The link between the first and second organisational identity perspectives outlined above was eventually made by Dutton et al. (1994). These authors concluded personal and social-fit, relevance and favourability of their perceived organisational identity traits (perspective one) has a bearing on the organisational identification of organisational members (perspective two).

\section{Organisational identity: impetuses}

Since Albert and Whetten's (1985) cornerstone article, the organisational identity notion has developed into a field which aims to understand identity and identification from an organisational member/organisational members. Research in this mature area of business identity studies has primarily an internal focus and mainly comprehends identity as a socially-constructed/social-psychological phenomenon at the level of individuals 


\section{2}

and/or groups or the dynamics between them in a work context (see Corley at al. 2006; Ashforth et al. 2008).

Also, the issue of multiple identities has also emerged as an issue of considerable import but within the organisational identity canon (Pratt and Foreman 2000; Foreman and Whetten 2002; Albert and Adams 2002; Pratt and Kraatz 2009) and corporate identity/corporate marketing canon too (Balmer 1994, 1996; Balmer and Wilson 1998; Leitch and Motion 1999; Balmer and Greyser 2002; He and Balmer 2007; Balmer 2011C). Significantly, it has come to the fore in the embryonic corporate heritage scholarship field (Balmer 2011b; 2013a).

Alas, space does not permit a full examination of the organisational identity/ organisational identification canon and its importance for organisational heritage but additional dimensions of the above can be found in Editorial Box 2.

INSERT EDITORIAL BOX 2 HERE

\section{Organisational memory (foundational literature)}

The third of the foundational literatures informing our designation of organisational heritage relates to organisational memory. By means of context, and as an aside, we note that the issue of memory - and the theory of memory - has been a significant concern in philosophical and psychological thought. For example, this can be seen in the work - and schools-of-thought - of the celebrated French philosopher Bergson in his "Matter and Memory" (1912) or Betrand Russell (1957. p.71) in noting the significance of memory stated:

"If memory is to be accepted as a source of knowledge, the past must be before the time now, and must therefore still exist."

In psychological thought, one interesting field of inquiry and one of saliency to corporate heritage and organisational memory is the notion of prospective memory and which 


\section{3}

conceptualises memory from the perspective of the future (see: McDaniel and Einstein 2007).

Understandably, the importance of memory has caused management scholars to explore this concept in organisational contexts and this has given rise to the nascent area of organisational memory. The organisational memory literature is concerned with processes of remembering and forgetting within organisations, viz: organisational memory. Among management scholars, two major perspectives or 'schools-of-thought' predominate the literature on the organisational memory phenomenon: (i) an emphasis on the instrumental/managerial, and (ii) an emphasis on the collective and symbolic.

\section{The instrumental and managerial relevance of organisational memory}

The first perspective focuses on the instrumental/managerial advantages of organisational memory in terms of strategic knowledge/information management and organisational learning (e.g., Walsh and Ungson, 1991; Anand et al. 1998; Olivera, 2000). As such, this literature is concerned with forms and processes of collating, storing, and retrieving organisational knowledge/ information amassed up over time and which, usually, is dispersed throughout an organisation. In terms of organisational memory, this knowledge/information aims to be universally accessible and contemporary management purposes.

The second school of thought adopts a more explicit theoretical and interpretative stance. Here organisational memory is seen as a collective and symbolic phenomenon and this perspective is of particular consequence for organisational identity and organisational identification (e.g., Nissley and Casey, 2002; Feldman and Feldman, 2006; Rowlinson et al. 2010; Anteby and Molnar, 2012; Decker, 2014; Adorisio, 2014). These schools of thought are further - albeit briefly - delineated in editorial box 3 .

\section{INSERT EDITORIAL BOX 3 HERE}




\section{4}

\section{The collective and symbolic relevance of organisational memory}

The second school-of-thought, which characterises organisational memory as a collective and symbolic phenomenon and is concerned with individual and collective meanings, shares parallels with our own conceptual thinking (see: Balmer 2013; Burghausen and Balmer 2014b). However, only a few management scholars recently - it seems to us have embraced this approach (e.g., Rowlinson et al, 2010; Anteby and Molnar, 2012; Decker, 2014).

Mystifyingly, some scholars (e.g., Schultz and Hernes, 2013) examine organisational memory along similar lines without apparent recourse to the pertinent scholarship on corporate heritage (see Balmer 2011b, 2013; Burghausen and Balmer, 2014b) nor to important extant contributions in the organisation and management field that advocate the second school-of-thought mentioned above (see: Rowlinson et al, 2010; Rowlinson et al, 2014a).

Encouragingly, though, we discern parallels between the second school-of-thought within the organisational memory canon and developments within the corporate heritage field. For instance, the corporate heritage domain recognises how a shared collective memory - and a positive collective memory - is important. For instance, Balmer (2011b p.1389) stated:

"Corporate heritage identities can be powerful because they are part of a group's collective memory vis-à-vis the institution per se and the institution's inextricable link with cultures, places and with time-frames."

The importance of the hermeneutic tradition has also been acknowledged and this can be relevant for organisational memory (Balmer 2011b p. 1395). Drawing on the work of Smith (1991) on nationality where collective memory can define nationality, Balmer (2013 p.303) concluded:

"... the notion of the shared collective memory - and positive collective memory at that - is one important dimension why corporate heritage identities are attractive."

We argue that something of the same applies to the organisational heritage notion too. 
Furthermore, corporate heritage institutions may affect and imbue identities (and identification) at the level of the group (Balmer 2013a). This line of thought is further specified and reflected in our notion of the repertoires of the corporate past (see: Burghausen and Balmer, 2014b). For example, the concept of corporate memory was defined as follows:

\footnotetext{
"the remembered and forgotten past of a company representing all forms of present knowledge (understanding and meaning) about an organisation's past that is constructed and reconstructed by processes and practices of remembering and forgetting at the individual, collective, and institutional level" (Burghausen and Balmer, 2014b, p. 391).
}

Corporate memory, to us, is expansive in that it refers to both, what is remembered and what is forgotten in relation to a corporate past: a past that variously manifests in cognitive, social, and cultural form within and without organisations. Our understanding of corporate memory is informed by sociological and cultural concepts of memory as articulated in the collective and cultural memory studies literatures (see: Erll, 2010; Olick et al, 2011 for an overview) and - to repeat - by scholarship on national identity (Gellner 1983; Smith 1991). Nationality represents one of at least five perspectives informing corporate heritage studies (Balmer, 2013a p. 304).

As such, our discernment of corporate memory refers to ideational and material forms of remembering and forgetting the past of an organisation and can be understood as a composite of: shared social interpretations of the past in the light of contemporary concerns that are derived from the exchange of individual memories related to an organisation as much as enacted through shared mnemonic practices (e.g. rituals, commemorations, past-related events) and manifested in the form of shared cultural artefacts as material traces of an organisation's past alike (see: Burghausen and Balmer, 2014b).

We argue that by drawing on the emergent literature on organisational memory our conceptualisation of organisation heritage, which is linked to and partially predicated on processes of remembering and forgetting the past, we can strengthen not only corporate heritage scholarship but also the conceptual relevance of organisational heritage management and organisation studies. Why is this so? 


\section{6}

This is because, organisational memory is relevant for organisational identity and identification (e.g., the perceived/claimed identity enduringness is based on the collectively shared memories amongst organisational members: how the past is remembered in the present impacts on the perceived continuity of identity traits) as well as organisational heritage (e.g., the selective appropriation and valorisation of the past into heritage requires recourse to organisational memory in order to make the past accessible in the present: the past needs to be remembered first before it can be valorised into heritage).

\section{DEFINING ORGANISATIONAL HERITAGE: THREE PERSPECTIVES}

In this section, we now specify our notion of organisational heritage. We outline three key, foundational, standpoints that delineate the construct. At this juncture, In explaining $g$ the elemental characterisations of organisational heritage, it is worth reiterating that these articulations are (a) informed by the literatures on corporate heritage, organisational identity/identification, and organisational memory and (b) are mindful of the prospective importance of organisational heritage identity and organisational heritage identification mentioned in Balmer and Chen (2015 p. 202) who noted:

\footnotetext{
"As such, the extant concepts of organisational identity, organisational identification can be adapted within a corporate heritage context viz: organisational heritage/organisational heritage identities and organisational heritage identification".
}

As such, three perspectives or schools-of-thought can be seen to be associated with three organisational heritage sub-constructs (see Figure 5), namely:

- Organisational heritage identity

- Organisational heritage identification

- Organisational heritage cultural identification.

Let us now explain this logic in more detail by showing how we have been mindful to build on and meaningfully advance nascent scholarship on corporate heritage along with more established insights from organisational identity: 


\section{7}

a) the observations in Balmer and Chen (2015 p. 202) who noted the potential importance of organisational heritage identity and organisational heritage identification;

b) extant delineations of corporate heritage as articulated in Burghausen and Balmer (2014b);

c) core perspectives within the organisational memory canon;

d) the principle distinctions in organisational identity scholarship (organisational identity as claimed identity traits by organisational members or as identification/self-categorisation vis-à-vis an organisation);

e) insights from both the identity-based views of the firm perspective of Balmer (2008), and the work of organisational behaviourists such as Ashforth and Mael (1989), in terms of identification to a corporate culture;

f) the definition of Balmer (2013a. p 318) vis-à-vis corporate heritage culture as: "The perennial sense of who we are on the part of successive generations of organisational members and, where applicable, owners (family owned businesses for example)"

\section{Figure 5: Three principal perspectives/schools-of-thought on organisational heritage}

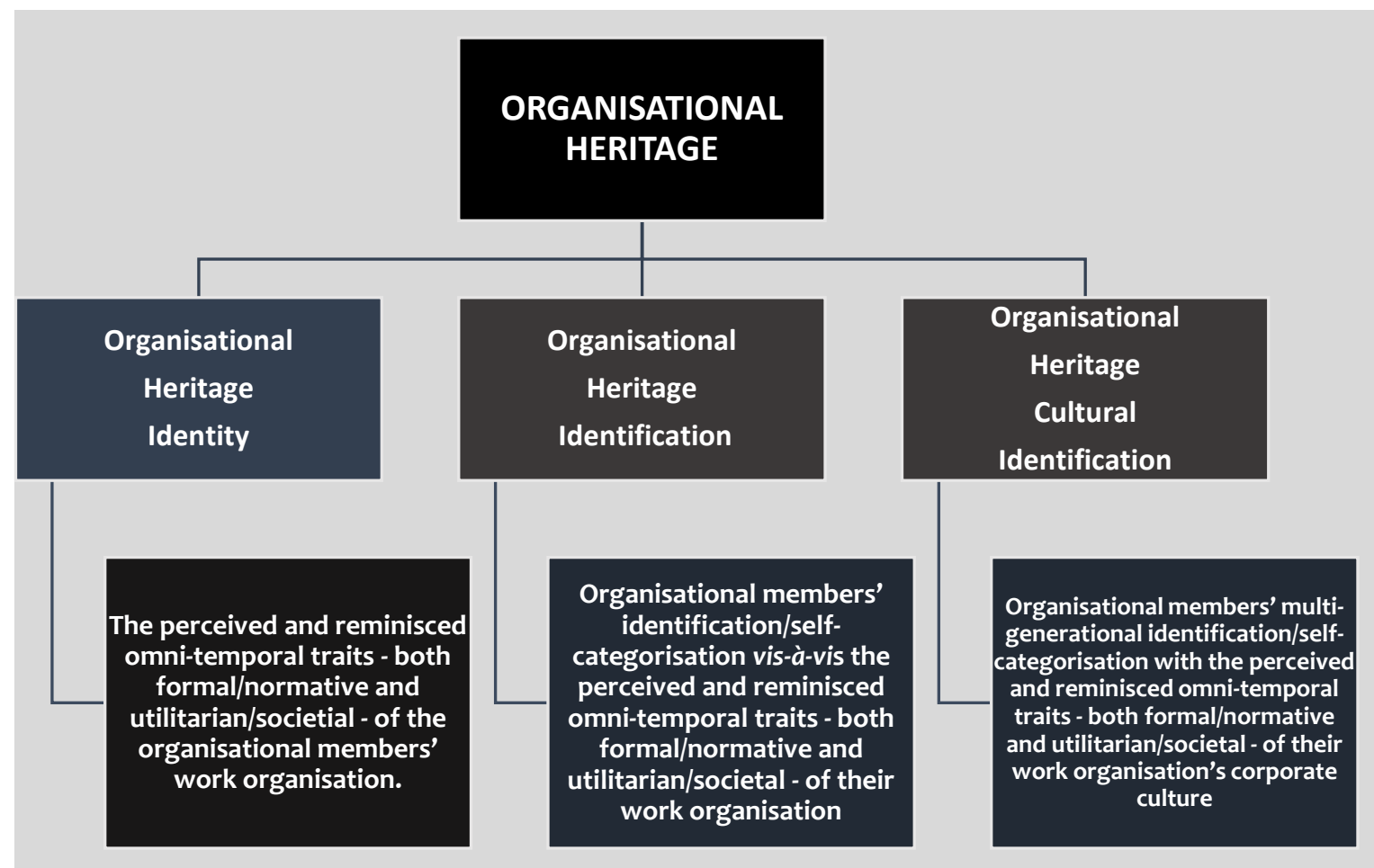

Organisational heritage can, therefore, be differentiated into three principle, yet interdependent, ways (see Figure 5): 


\section{8}

1. Organisational heritage identity: The perceived and reminisced omni-temporal traits - both formal/normative and utilitarian/societal - of organisational members' work organisation.

2. Organisational heritage identification: Organisational members' identification/self-categorisation vis-à-vis the perceived and reminisced omnitemporal traits - both formal/normative and utilitarian/societal - of their work organisation.

3. Organisational heritage cultural identification: Organisational members' multigenerational identification/self-categorisation vis-à-vis the perceived and reminisced omni-temporal traits - both formal/normative and utilitarian/societal of their work organisation's corporate culture.

Some further reflections on the three schools of thought and the logic underpinning their formal introduction will be found in Editorial Box 4.

INSERT EDITORIAL BOX 4 HERE

\section{DISCUSSION}

\section{Organisational identity: of significance to corporate brand management}

Clearly, the organisational heritage standpoint is of particular significance to corporate heritage brands and their management where, clearly, organisational heritage, organisational heritage identification and organisational heritage culture identification are of significance and can be equally applied to corporate heritage brands as they can to corporate heritage identities.

As readers of JBM will recall, from its inception, the corporate brand concept has stressed the importance of personnel (Balmer 1995). This can be seen in the internal/employee branding and corporate brand orientation literatures (see: Punjaisri and Wilson 2007; Davies 2008; Balmer 2013b). Of course, the importance of member identification with a corporate brand has emerged as a significant theme within the corporate brand literature (Balmer and Liao 2007; Balmer et al. 2010). As such, in corporate heritage brand contexts, the organisational heritage notion - and the three principal schools of thought 


\section{9}

introduced and delineated in this article - has the real potential to be of value and of interest to corporate brand scholars and managers alike.

In particular, the question of how and why individuals and groups attach worth to corporate heritage brands is likely to be of interest to corporate brand scholars and practitioners alike. In addition, our overview of organisational heritage is of obvious significance in terms of the meanings and affinities organisational members (including managers and other organisational members) attach to their institution's corporate heritage brands. Of course, organisational heritage is especially salient for corporate heritage services brands where organisational members are of critical importance in that they are "the face" of the corporate heritage brand vis-à-vis other stakeholders.

\section{Further research}

We believe our explication of three foundational perspectives on organisational heritage provides a platform for further research and scholarship.

For instance, empirical research could examine how and why organisational members identify with a corporate heritage brand and the possible (positive and negative) implications of this affiliation. Such an approach could build on the initial on corporate brand identification (Balmer and Liao 2007, Balmer et al 2010).

Another aspect recommending itself for empirical scrutiny relates to the process of appropriation and valorisation of past corporate heritage brand traits and may explain how and when certain identity traits become salient and remain their relevance over time. A better understanding of these identification processes might also be applicable to other (external) corporate brands stakeholders and may help to explain the strength of corporate heritage brands as a point of reference across generations of stakeholders.

Also, the organisational heritage notion is likely to be particularly relevant for multigenerational family corporate heritage businesses and their corporate heritages well, as argued by Balmer (2013a. p.318) and may facilitate their corporate brand management activities. 


\section{0}

In addition, issues surrounding identification to normative as well as to societal heritage identities along with multi-generational identification to a corporate heritage culture also merits further deliberation and, of course, research.

Furthermore, the notion of perceived organisational heritage traits and as a practice/process of identification to a corporate heritage entity/culture may help to conceptually advance our understanding of the problem of perceived/claimed enduringness and stability of organisational identities and identification due to its explicit Omni-temporal characteristics of corporate heritage institutions. In particular, the corporate heritage marketing notion of concurrent retrospective and prospective sensemaking and sense-giving which also underpins organisational heritage is, arguably, of conceptual importance. To date, this important aspect has not been captured/discussed by scholars of organisational identity or within the nascent organisational memory domain.

Clearly, too, the notion of multi-generational affiliation and identification has the potential to illuminate and advance our understanding of inter-generational group development within organisations. Finally, the specific characteristics of corporate heritage entities as often dual identities may advance our understanding how and when different identities and identifications function in a mutually reinforcing and complementary rather than only in a conflicting way: the latter has been a key focus in the extant literature on multiple organisational identities.

\section{CONCLUSION}

Our formal introduction and elaboration of the organisational heritage notion, we hope, meaningfully advances our conceptual understanding of corporate heritage identities and corporate heritage brands. Both constitute salient reference points for stakeholder identification and as we have deliberated in this article for organisational members in particular.

Clearly, the three schools-of-thought outlined in this article are interrelated and have the potential to facilitate our understanding of how and why corporate heritage brands may become salient and maintain their relevance over time for organisational members. 
Of course, our formal introduction of the organisational heritage notion builds on the preliminary insights in the literature - especially the notion that organisational heritage/organisational heritage identification as concepts were likely to be of significance (Balmer and Chen 2015) - and represents an initial explication of the organisational heritage notion which merits a more detailed examination.

It is our hope that this article will be of interest to scholars and managers of corporate brand management and to scholars within the fields of organisational behaviour and management focussing on organisational identity and organisational memory. More particularly, we envision this article will be of especial pertinence to the small, but growing, number of scholars - and prospectively managers too-within the corporate marketing domain sharing our research interests in the broad corporate heritage field. 


\section{2}

\section{REFERENCES}

Adorisio, A. L. M. (2014) Organizational remembering as narrative: 'Storying' the past in banking. Organization 21(4): 463-476.

Albert, S. and Adams, E. (2002) The hybrid identity of law firms. In: Moingeon, B. and Soenen, G. B.(eds.) Corporate and Organizational Identities. Integrating Strategy, Marketing, Communication and Organizational Perspectives. London: Routledge, pp. 35-50.

Albert, S. and Whetten, D. A. (1985) Organizational identity. Research in Organizational Behavior 7: 263-295.

Anand, V., Manz, C. C. and Glick, W. H. (1998) An organizational memory approach to information management. Academy of Management Review 23(4): 796-809.

Anteby, M. and Molnar, V. (2012) Collective memory meets organizational identity: Remembering to forget in a firm's rhetorical history. Academy of Management Journal 55(3): 515-540.

Ashforth, B. E., Harrison, S. H. and Corley, K. G. (2008) Identification in organizations: An examination of four fundamental questions. Journal of Management 34(3): 325-374.

Ashforth, B. E. and Mael, F. (1989) Social Identity Theory and the Organization. Academy of Management Review 14(1): 20-39.

Balmer, J. M. T. (1994) The BBC's corporate identity: Myth, paradox and reality. Journal of General Management 19(3): 33-49.

Balmer, J. M. T. (1995) Corporate branding and connoisseurship. Journal of General Management 21(1): p24- 46.

Balmer, J.M.T. (1996) The Nature of Corporate Identity: An Explanatory Study Undertaken within BBC Scotland, PhD, Department of Marketing, University of Strathclyde, Glasgow, Scotland.

Balmer, J. M. T. (2008) A Resource-Based View of the British Monarchy as a Corporate Brand. International Studies of Management and Organization 37(4): 20-44.

Balmer, J. M. T. (2009) Scrutinising the British Monarchy: The corporate brand that was shaken, stirred and survived. Management Decision 47(4): 639-675.

Balmer, J. M. T. (2011a) Corporate heritage brands and the precepts of corporate heritage brand management: Insights from the British Monarchy on the eve of the royal wedding of Prince William (April 2011) and Queen Elizabeth II's Diamond Jubilee (19522012). Journal of Brand Management 18(8): 517-544.

Balmer, J. M. T. (2011b) Corporate heritage identities, corporate heritage brands and the multiple heritage identities of the British Monarchy. European Journal of Marketing 45(9/10): 1380-1398.

Balmer, J. M. T. (2011c) Corporate marketing myopia and the inexorable rise of a corporate marketing logic: Perspectives from identity-based views of the firm. European Journal of Marketing 45(9/10): 1329-1352.

Balmer, J. M. T. (2013a) Corporate heritage, corporate heritage marketing, and total corporate heritage communications. Corporate Communications: An International Journal 18(3): 290-326.

Balmer, J. M. T. (2013b) Corporate brand orientation: What is it? What of it? Journal of Brand Management 20(9): 723-741.

Balmer, J. M. T. (2012) Strategic corporate brand alignment: Perspectives from identity based views of corporate brands. European Journal of Marketing 46(7/8): 1064-1092.

Balmer, J. M. T. (2014) Wally Olins (1930-2014), corporate identity ascendancy and corporate brand hegemony. Celebrating the life of Wally Olins: Leading corporate 


\section{3}

identity exponent and prominent brand proponent. Journal of Brand Management 21(6): 459-468.

Balmer, J. M. T. (2015) Corporate identity, corporate identity scholarship and Wally Olins (1930-2014). Corporate Communications: An International Journal 20(1): 4-10.

Balmer, J. M. T. and Burghausen, M. (2015) Explicating corporate heritage, corporate heritage brands, and organisational heritage. Journal of Brand Management

Balmer, J. M. T. and Chen, W. (2015) Corporate heritage brands in China. Consumer engagement with China's most celebrated corporate heritage brand - Tong Ren Tang: 同仁堂. Journal of Brand Management 22(3): 194-210.

Balmer, J. M. T. and Greyser, S. A. (2002) Managing the multiple identities of the corporation. California Management Review 44(3): 72-86.

Balmer, J. M. T. and Greyser, S. A. (eds.) (2003) Revealing the Corporation: Perspectives on Ddentity, Image, Reputation, Corporate Branding, and Corporate-Level Marketing. An Anthology. London: Routledge.

Balmer, J. M. T. and Greyser, S. A. (2006) Corporate marketing: Integrating corporate identity, corporate branding, corporate communications, corporate image and corporate reputation. European Journal of Marketing 40(7/8): 730-741.

Balmer, J. M. T., Greyser, S. A. and Urde, M. (2006) The Crown as a corporate brand: Insights from monarchies. Journal of Brand Management 14(1/2): 137-161.

Balmer, J.M.T. and Liao, M-N. (2007) Student corporate brand identification: an exploratory case

Study. Corporate Communication: An International Journal 12(4):356-375.

Balmer, J.M.T., Liao, M-N, and Wang, W-Y (2010) Corporate brand identification and corporate brand management: how top business schools do it. Journal of General Management 35(4): 72-102.

Balmer, J. M. T. and Wilson, A. M. (1998) Corporate identity: There is more to it than meets the eye. International Studies of Management and Organization 28(3): 12-31.

Bargenda, A. (2015) Corporate heritage brands in the financial sector: The role of corporate architecture. Journal of Brand Management advance online publication, May 15, 2015.

Bendix, R. (2009) Heritage between economy and politics: An assessment from the perspective of cultural anthropology. In: Smith, L. and Akagawa, N.(eds.) Intangible Heritage. London: Routledge, pp. 253-269.

Bergson, G. (2004, (1912) Matter and Memory. London: George Allen and Co. Ltd.

Bhattacharya, C. B. and Sen, S. (2003) Consumer-company identification: A framework for understanding consumers' relationships with companies. Journal of Marketing 67(4): 76-88.

Birkigt, K. and Stadler, M. M. (eds.) (1980) Corporate Identity: Grundlagen, Funktionen, Fallbeispiele. Munich: Verlag Moderne Industrie.

Blombäck, A. and Brunninge, O. (2009) Corporate identity manifested through historical references. Corporate Communications: An International Journal 14(4): 404-419.

Bouchikhi, H. and Kimberly, J. R. (2008) The Soul of the Corporation: How to Manage the Identity of Your Company. Upper Saddle River: Wharton School Publishing.

Brunninge, O. (2009) Using history in organisations: How managers make purposeful reference to history in strategy processes. Journal of Organizational Change Management 22(1): 8-26.

Burghausen, M. and Balmer, J. M. T. (2014a) Corporate heritage identity management and the multi-modal implementation of a corporate heritage identity. Journal of Business Research 67(11): 2311-2323. 


\section{4}

Burghausen, M. and Balmer, J. M. T. (2014b) Repertoires of the corporate past: Explanation and framework. Introducing an integrated and dynamic perspective. Corporate Communications: An International Journal 19(4): 384-402.

Burghausen, M. and Balmer, J. M. T. (2015) Corporate heritage identity stewardship: A corporate marketing perspective. European Journal of Marketing 49(1/2): 22-61.

Burmann, C. and Zeplin, S. (2005) Building brand commitment: A behavioural approach to internal brand management. Journal of Brand Management 12(4): 279-300.

Carroll, C. E. (2002) Introduction: The strategic use of the past and future in organizational change. Journal of Organizational Change Management 15(6): 556-562.

Carson, P. P. and Carson, K. D. (2003) An exploration of the importance of history to managers: The meaningful, manipulative, and memorable uses of milestones. Organizational Dynamics 32(3): 286-308.

Chandler, A. D. (1962) Strategy and Structure. Boston: MIT Press.

Chreim, S. (2005) The continuity-change duality in narrative texts of organizational identity. Journal of Management Studies 42(3): 567-593.

Cooper, H., Merrilees, B. and Miller, D. (2015a) Corporate heritage brand management: Corporate heritage brands versus contemporary corporate brands. Journal of Brand Management advance online publication, May 22, 2015.

Cooper, H., Miller, D. and Merrilees, B. (2015b) Restoring luxury corporate heritage brands: From crisis to ascendency. Journal of Brand Management advance online publication, May 15, 2015.

Corley, K. G., Harquail, C. V., Pratt, M. G., Glynn, M. A., Fiol, C. M. and Hatch, M. J. (2006) Guiding Organizational Identity Through Aged Adolescence. Journal of Management Inquiry 15(2): 85-99.

Cornelissen, J. P., Haslam, S. A. and Balmer, J. M. T. (2007) Social identity, organizational identity and corporate identity: Towards an integrated understanding of processes, patternings and products. British Journal of Management 18(s1): S1-S16.

Davies, G. (2008) Employer branding and its influence on managers. European Journal of Marketing 42(5/6): $667-681$.

Decker, S. (2014) Solid intentions: An archival ethnography of corporate architecture and organizational remembering. Organization 21(4): 514-542.

Delahaye, A., Booth, C., Clark, P., Procter, S. and Rowlinson, M. (2009) The genre of corporate history. Journal of Organizational Change Management 22(1): 27-48.

Ericson, M. (2006) Exploring the future exploiting the past. Journal of Management History 12(2): 121-136.

Erll, A. (2010) Cultural memory studies: An introduction. In: Erll, A. and Nünning, A.(eds.) A Companion to Cultural Memory Studies: An International and Interdisciplinary Handbook. Berlin: de Gruyter, pp. 1-15.

Feldman, R. M. and Feldman, S. P. (2006) What Links the Chain: An Essay on Organizational Remembering as Practice. Organization 13(6): 861-887.

Foreman, P. and Whetten, D. A. (2002) Members' identification with multiple-identity organizations. Organization Science 13(6): 618-635.

Foster, W. M., Suddaby, R., Minkus, A. and Wiebe, E. (2011) History as social memory assets: The example of Tim Hortons. Management \& Organizational History 6(1): 101120.

Gellner, E. (1983) Nations and nationalism. London: Blackwell.

Gioia, D. A., Corley, K. G. and Fabbri, T. (2002) Revising the past (while thinking in the future perfect tense). Journal of Organizational Change Management 15(6): 622-634.

Gioia, D. A., Schultz, M. and Corley, K. G. (2000) Organizational identity, image, and adaptive instability. Academy of Management Review 25(1): 63-81. 


\section{5}

Gioia, D. A. and Thomas, J. B. (1996) Identity, image, and issue interpretation: Sensemaking during strategic change in academia. Administrative Science Quarterly 41(3): 370-403.

Haslam, S. A., Reicher, S. and Platow, M. (2011) The New Psychology of Leadership: Identity, Influence, and Power. Hove: Psychology Press.

Hatch, M. J. and Schultz, M. (2004) Introduction. In: Hatch, M. J. and Schultz, M.(eds.) \& M. J. Hatch \& M. Schultz (Vol. Eds.) Oxford Management readers. Organizational Identity. A Reader. Oxford: Oxford University Press, pp. 1-6.

He, H.-W. and Balmer, J. M. T. (2007) Identity studies: Multiple perspectives and implications for corporate-level marketing. European Journal of Marketing 41(7/8): 765785.

Hudson, B. T. (2011) Brand heritage and the renaissance of Cunard. European Journal of Marketing 45(9/10): 1538-1556.

Hudson, B. T. and Balmer, J. M. T. (2013) Corporate heritage brands: Mead's theory of the past. Corporate Communications: An International Journal 18(3): 347-361.

Jones, G. and Zeitlin, J. (2009) Introduction. In: Jones, G. and Zeitlin, J. (eds.) The Oxford Handbook of Business History. Oxford: Oxford University Press, pp. 1-6.

Jugel, S., Wiedmann, K.-P. and Kreutzer P. (1987) Die Formulierung der Unternehmensphilosophie im Rahmen einer Corporate Identity-Strategie. MarketingZFP 9(4): 293-303.

Kimberly, J. R. and Bouchikhi, H. (1995) The dynamics of organizational development and change: How the past shapes the present and constrains the future. Organization Science 6(1): 9-18.

Koselleck, R. (1989, @1979) Vergangene Zukunft: Zur Semantik geschichtlicher Zeiten, Suhrkamp Taschenbuch Wissenschaft: Vol. 757. Frankfurt am Main: Suhrkamp.

Larçon, J. P. and Reitter, R. (1979) Structures de pouvoir et identité de l'entreprise. Paris: F. Nathan.

Larçon, J. P. and Reitter, R. (1984) Corporate imagery and corporate identity. In: Kets de Vries, M. F. R. (ed.) The Irrational executive. Psychoanalytic Explorations in Management. New York: International Universities Press, pp. 344-355.

Leitch, S. and Motion, J. (1999) Multiplicity in corporate identity strategy. Corporate Communications: An International Journal 4(4): 193-200.

Maclean, M., Harvey, C., Sillince, J. A. A. and Golant, B. D. (2014) Living up to the past? Ideological sensemaking in organizational transition. Organization 21(4): 543-567.

McDaniel, M. A., and Einstein, G. O. (2007) Prospective Memory: An Overview and Synthesis of an Emerging Field. Thousand Oaks, CA: Sage.

Moingeon, B. and Ramanantsoa, B. (1997) Understanding corporate identity: The French school of thought. European Journal of Marketing 31(5/6): 383-395.

Nissley, N. and Casey, A. (2002) The politics of the exhibition: viewing corporate museums through the paradigmatic lens of organizational memory. British Journal of Management 13(S2): S35-S45.

Olick, J. K., Vinitzky-Seroussi, V. and Levy, D. (2011) Introduction. In: Olick, J. K.; VinitzkySeroussi, V. and Levy, D.(eds.) The Collective Memory Reader. Oxford: Oxford University Press, pp. 3-62.

Olins, W. (1978) The Corporate Personality: An Inquiry Into the Nature of Corporate Cdentity. Design Council: London.

Olins, W. (1989) Corporate Identity: Making Business Strategy Visible Through Design. London: Thames and Hudson.

Olivera, F. (2000) Memory systems in organizations: An empirical investigation of mechanisms for knowledge collection, storage and access. Journal of Management Studies 37(6): 811-832. 


\section{6}

Ooi, C. (2002) Persuasive histories: Decentering, recentering and the emotional crafting of the past. Journal of Organizational Change Management 15(6): 606-621.

Parker, M. (2002) Contesting histories: Unity and division in a building society. Journal of Organizational Change Management 15(6): 589-605.

Pérez, A. and del Bosque, I. R. (2014) Organizational and corporate identity revisited: Toward a comprehensive understanding of identity in business. Corporate Reputation Review 17(1): 3-27.

Podnar, K., Golob, U. and Jančič, Z. (2011) Identification with an organisation as a dual construct. European Journal of Marketing 45(9/10): 1399-1415.

Pratt, M. G. and Foreman, P. O. (2000) Classifying managerial responses to multiple organizational identities. Academy of Management Review 25(1): 18-42.

Pratt, M. G. and Kraatz, M. S. (2009) E pluribus unum: Multiple identities and the organizational self. In: Roberts, L. M. and Dutton, J. E.(eds.) Exploring positive identities and organizations. Building a theoretical and research foundation. New York: Routledge, pp. 385-410.

Punjaisri, K and Alan Wilson, W. (2007) The role of internal branding in the delivery of employee brand promise. Journal of Brand Management 25(1): 57-70.

Ravasi, D. and Schultz, M. (2006) Responding to organizational identity threats: Exploring the role of organizational culture. Academy of Management Journal 49(3): 433-458.

Ries, A. and Trout, J. (1981) Positioning: The Battle For Your Mind. New York: McGraw Hill.

Rindell, A, Santos, F. P. and de Lima, A. P. (2015) Two sides of a coin: Connecting corporate brand heritage to consumers' corporate image heritage. Journal of Brand Management in press

Rowlinson, M., Booth, C., Clark, P., Delahaye, A. and Procter, S. (2010) Social Remembering and Organizational Memory. Organization Studies 31(1): 69-87.

Rowlinson, M., Casey, A., Hansen, P. H. and Mills, A. J. (2014a) Narratives and memory in organizations. Organization 21(4): 441-446.

Russell, B. (1957) History of Western Philosophy, London: George Allen and Unwin. ( $6^{\text {th }}$ Edition)

Schreyögg, G., Sydow, J. and Holtmann, P. (2011) How history matters in organisations: The case of path dependence. Management \& Organizational History 6(1): 81-100.

Schroeder, J., Borgerson, J. and Wu, Z. (2015) A brand culture approach to Chinese cultural heritage brands. Journal of Brand Management 22(3): 261-279.

Schultz, M. and Hernes, T. (2013) A temporal perspective on organizational identity. Organization Science 24(1): 1-21.

Smith, A. D. (1991) National identity. London: Penguin.

Stuart, H. J. (2002) Employee Identification with the Corporate Identity. International Studies of Management \& Organization 32(3): 28-44.

Stuart, H. J. (2012) Living the Corporate Rebrand: The Employee Perspective. Corporate Reputation Review 15(3): 158-168.

Suddaby, R., Foster, W. M. and Quinn-Trank, C. (2010) Rhetorical history as a source of competitive advantage. In: Baum, J. A. C. and Lampel, J. (Vol. Eds.) Advances in Strategic Management: Vol. 27. The globalization of strategy research. Bingley: Emerald: 147-173.

Tagiuri, R. (1982) Managing corporate identity: the role of top management, Invited address delivered at the International seminar on corporate identity building, Centre d'enseignement et de recherché appliques au management, Sophia Antipolis, France (March 25-26).

Tajfel, H. (1982) Social Psychology of Intergroup Relations. Annual Review of Psychology 33(1): $1-39$. 


\section{7}

Turner, J. C. (1975) Social comparison and social identity: Some prospects for intergroup behaviour. European Journal of Social Psychology 5(1): 1-34.

Urde, M., Greyser, S. A. and Balmer, J. M. T. (2007) Corporate brands with a heritage. Journal of Brand Management 15(1): 4-19.

Vallaster, C. and de Chernatony, L. (2006) Internal brand building and structuration: The role of leadership. European Journal of Marketing 40(7/8): 761-784.

Walsh, I. J. and Glynn, M. A. (2008) The way we were: Legacy organizational identity and the role of leadership. Corporate Reputation Review 11(3): 262-276.

Walsh, J. P. and Ungson, G. R. (1991) Organizational memory. Academy of Management Review 16(1): 57-91.

Weick, K. E. (1995) Sensemaking in Organizations. Foundations for Organizational Science. Thousand Oaks, CA: Sage Publications.

Whetten, D.A. and Godfrey, P.C. (ed) (1998) Identity in Organizations. Building Theory Through Conversations, , Thousand Oaks, CA: Sage Publications.

Whetten, D. A. and Mackey, A. (2002) A social actor conception of organizational identity and its implications for the study of organizational reputation. Business \& Society 41(4): 393-414.

Wiedmann, K.-P., Hennigs, N., Schmidt, S. and Wuestefeld, T. (2011a) Drivers and Outcomes of Brand Heritage: Consumers' Perception of Heritage Brands in the Automotive Industry. Journal of Marketing Theory \& Practice 19(2): 205-220.

Wiedmann, K.-P., Hennigs, N., Schmidt, S. and Wuestefeld, T. (2011b) The importance of brand heritage as a key performance driver in marketing management. Journal of Brand Management 19(3): 182-194.

Ybema, S. (2010) Talk of change: Temporal contrasts and collective identities. Organization Studies (01708406) 31(4): 481-503.

Ybema, S. (2014) The invention of transitions: History as a symbolic site for discursive struggles over organizational change. Organization 21(4): 495-513.

Zerubavel, E. (2004) Time maps: Collective memory and the social shape of the past. Chicago: University of Chicago Press. 


\section{EDITORIAL BOX 1: THE PAST/TEMPORALITY IN CORPORATE MARKETING AND MANAGEMENT}

The broad corporate heritage notion emerged from empirical research of monarchies (Balmer et al. 2006). From this it was deemed that certain monarchies (such as the British and Swedish) and, more generally a genus of institution (encompassing many organisations) can be characterised as corporate heritage brands.

Corporate heritage is concurrently concerned with retrospective links to the past and prospective links to the future that imbue an organisation with symbolic relevance and legitimacy vis-à-vis multiple stakeholder groups and individuals within and outside the organisation (Balmer, 2011b; Burghausen and Balmer, 2014b).

In addition, the appropriation of material and/or ideational organisational traits or aspects of the past as corporate heritage requires valorisation - the continued imbuement with new value in the present - which is predicated on an active interpretation and reinterpretation of the past by individuals and collectives in the present. The theoretical notion of relative invariance (Balmer 2011b) encompasses an analogous perspective. As such, heritage and its articulation as corporate heritage is closely related to the question of how and why individuals and groups of people refer to something as heritage of the organisation in the first place and how it is qualitatively different from the past per se.

The management literature and temporal phenomena

To substantiate our initial claim that it is time to extend our vista beyond the confines of brand management, corporate marketing and corporate communication, a cursory scrutiny of extant management and organisational literature reveals not dissimilar interests in temporal phenomena, which have informed corporate heritage scholarship for a significant period of time now; not least through seminal contributions in this journal (e.g., Balmer et al, 2006; Urde et al, 2007; Balmer, 2011b).

As such, we notice that within the realm of management and organisation studies the relevance of historical references and retrospection has been acknowledged and is variously discussed (e.g., Weick, 1995; Carroll, 2002; Gioia et al, 2002; Nissley and Casey, 2002; Ooi, 2002; Parker, 2002; Carson and Carson, 2003; Chreim, 2005; Ericson, 2006; Walsh and Glynn, 2008; Brunninge, 2009; Delahaye et al, 2009; Suddaby et al, 2010; Foster et al, 2011; Anteby and Molnar, 2012; Schultz and Hernes, 2013; MacLean et al, 2014). This literature has discussed the relevance of the past, for instance:

(1) in regard to management communication with internal and external stakeholders;

(2) in the context of organisational identity and identification within organisations;

(3) in relation to sense-making and sense-giving activities;

(4) in terms of the legitimation and implementation of organisational change, managerial agendas, innovation and corporate strategies. 


\section{EDITORIAL BOX 2: ORGANISATIONAL IDENTITY/ORGANISATIONAL IDENTIFICATION}

\section{Corporate Marketing complementing Organisational Identity}

The particular focus of organisational behaviourists and management scholars on the internal/employee-focussed facets of identity, clearly, could be complemented by a more outward-oriented, strategic, and applied approach that underpins the corporate marketing field. This can be seen in addressing the question: "What makes an organisation meaningfully distinct" vis-à-vis other organisations and various stakeholder groups and how this affects identification of organisational members but also other (external) stakeholders (see Balmer 2008). For example, corporate marketing scholarship has shown that employee identification is a multi-level phenomenon operating at the group (cultural) and corporate (institutional) level at once (Balmer 2008; Podnar et al 2011) while being also relevant for external stakeholders, such as consumers (Bhattacharya and Sen, 2003). From a corporate marketing point of view we see merit in the view that - in the 'age of identity' (Bouchikhi and Kimberly 2008) - senior managers are first and foremost 'identity entrepreneurs' (Haslam et al. 2011) vis-à-vis internal but also external constituents.

Claimed identity enduringness: importance to corporate heritage and organisational heritage?

The third identity criterion of Albert and Whetten (1985) the notion of claimed identity enduringness as originally articulated by Albert and Whetten (1985) - and its link to organisational identification - is of paramount importance here. It is this aspect where its importance has also been noted within the corporate heritage field where the following was articulated: "The perennial sense of who we are on the part of successive generations of organisational members and, where applicable, owners (family-owned businesses for example)" (Balmer, 2013. p. 318). The criterion of claimed identity enduringness refers broadly to questions of stability, continuity, coherence and self-sameness of organisational identity traits over time. As such, the question of temporality and historicity of organisational identity is central to its understanding.

\section{Claimed identity stability: importance to corporate heritage and organisational heritage?}

Albert and Whetten (1985) envisioned organisational identity traits to be fairly stable over time - changing only slowly - to have any bearing on organisational members' identity claims. Not surprisingly, the extant organisational identity literature has focused on issues of organisational change and its interdependence with organisational identity and identification. As such, the literature has variously addressed the conditions, characteristics, processes and outcomes of identity change, and whether identity change is at all possible, advantageous or detrimental to organisational identification or the organisation per se (Corley et al 2006). The literature has also discussed the extent of managerial agency and member resistance to identity threats that may require or induce a change in organisational identity or some form of adaptive behaviour (Dutton and Dukerich 1991; Ravasi and Schultz 2006; also see Haslam et al. 2011). This perspective seemingly has a bearing on Balmer's (2013) notion of trait constancy.

\section{Revision of history}

While questions of stability and adaptation of organisational identity have been mainly discussed as a concern for identity claims in and about the present, there is an emerging stream of scholarship that focuses on the 'revision of history' as an active interpretive process of sense making and sense giving within organisations (by management and employees) in order to re-establish the continuity between past and present (Gioia et al, 2000; Gioia et al, 2002; Chreim, 2005). As such, the past is not merely seen as a contingent factor but as a symbolic resource for organisational identity and identification within organisations (Brunninge, 2009). While this literature is important in its contribution to a better understanding of organisational identity and identification as temporal phenomena - not only predicated on present identity traits and claims but meaningfully linked to the past through the active narration and negotiation of the past in light of present concerns - it is mainly focused on retrospective sense-making (by members) and sense-giving (by managers). We argue that the envisaged notion of organisational heritage can expand the symbolic relevance of the past also into the future due to its Omni-temporality as a concept but also as a phenomenon. Notably, the study of the Tong Ren Tang corporate heritage institution (Balmer and Chen 2015 ) confirmed the stability and enduringness of corporate heritage institutions/corporate heritage brands and suggests that whilst the theoretical perspectives of the aforementioned can be challenged in relation to corporate identities they are significantly-but not wholly-germane in the context of corporate heritage institutions/corporate heritage brands. 


\section{EDITORIAL BOX 3: ORGANISATIONAL MEMORY. DELINEATING THE TWO SCHOOLS OF THOUGHT AND DIFFERENCES WITH ORGANISATIONAL HERITAGE}

The extant management and organisational literature has largely focused on two temporal concepts: organisational memory and organisational history.

\section{Organisational Memory: Schools-of-thought}

Two, distinct, approaches predominate management scholars understanding of organisational memory.

First school-of-thought: instrumental significance of organisational memory

The first school of thought conceptualises organisational memory in broadly instrumental terms. As such, it is regarded as being highly salient for (a) strategic knowledge, (b) for information management and, more generally, for (c) organisational learning. This helps explain why this approach focuses on the sources, accessibility, storage and transferability of tacit and explicit forms of individual and shared knowledge of - or from - the past) within organisations (e.g., Walsh and Ungson, 1991; Anand et al, 1998; Olivera, 2000). This school of thought predominated when management scholars first showed interest in the area.

Second school-of-thought: sociological/cultural nature of organisational memory and its impact on organisational identity and organisational identification.

The second school of thought conceptualises organisational memory as a dynamic and collective phenomenon and adopts a more theoretical rather than instrumental in character. The interpretive nature of organisational memory is stressed. In particular, this perspective marshals sociological and social-psychological theories which are closely intertwined with organisational identity and identification issues within organisations (e.g., Nissley and Casey, 2002; Feldman and Feldman, 2006; Rowlinson et al, 2010; Anteby and Molnar, 2012; Decker, 2014; Adorisio, 2014). Moreover, this second school of thought focuses on the processes and activities of (collective) remembering and forgetting among organisational members (Anteby and Molnar, 2012) or, more specifically within distinct organisational types such as corporate museums (Nissley and Cassey, 2002). More recently, this school of approach has begun o recognise the symbolic and socio-cultural relevance of the field.

\section{Differences between organisational memory and organisational heritage}

For us, organisational heritage, substantively different from organisational memory because:

Drawing on our earlier conceptual framework that articulated the importance of past related constructs (see Balmer 2011b) along with the repertoires of the corporate past perspective (see Burghausen and Balmer, 2014b), we argue that the valorisation of organisational memories, organisational histories or organisational traditions as organisational heritage expands their temporal reach and relevance for the members of the organisation. Put another way, an organisation's past might manifest in material and ideational form in the present as individually embodied or collectively shared organisational memories amongst members of an organisation.

However, organisational memories are nonetheless retrospective in focus and content in that they refer to the remembered (and also sometimes forgotten) organisational past. Yet, organisational memories that are valorised as organisational heritage by the members of an organisation take on a different quality. Their relevance for organisational members in the present - of such organisational memories thus valorised by them into organisational heritage - is not solely derived from a retrospective link to the past predicted on processes of commemoration, recollection and reminiscence but concurrently from a prospective link to the future based on envisioning its continued relevance for the future. While organisational memories stabilise collective organisational identity claims in the present, organisational heritage - through the process of valorisation - "ennobles" (we borrow this notion from Bendix, 2009) such memories as being particularly relevant for the future of the organisation as well. 


\title{
EDITORIAL BOX 4: CONTEXTUAL INFORMATION ON ORGANISATIONAL HERITAGE IDENTITY, IDENTIFICATION, AND CULTURAL IDENTIFICATION
}

\author{
1 Organisational heritage identity \\ The first perspective on organisational heritage refers to the claimed heritage identity traits of an organisation as \\ conceived by organisational members. As such, claimed organisational heritage traits may become to be seen by \\ organisational members as being central, distinctive and enduring in addition. This would qualify organisational heritage \\ traits (which are often but not necessarily central and distinctive) as organisational heritage identity traits. As such, they \\ constitute the traits of a particular type of organisational identity viz: organisational heritage identity.
}

The above approach has clear links to the notion of corporate heritage identities (and by implication corporate heritage brands) as particular types of corporate identity where corporate heritage is meaningful. In a similar vein, organisational heritage identities are characterised by organisational members according importance to organisational heritage traits as being defining traits of 'who we understand we are' as an organisation (i.e., not any organisation but a heritage organisation).

The logic for this perspective is outlined below.

From a corporate heritage perspective: The very existence of a corporate heritage is a pre-requisite for organisational heritage. Without a corporate identity, organisational identity claims cannot be made and similarly, without a corporate heritage identity, an organisational heritage identity cannot subsist. As noted by Larçon and Reitter (1979) identity confers an institution with specificity, stability, and coherence and these criteria - whilst they may not always be applicable to all corporate identities all the time - are particularly apposite for corporate heritage entities (Balmer and Chen, 2015). The notion of institutional role identities/augmented role identities is also relevant here since corporate heritage institutions are imbued with both normative/formal "corporate" identities but also societial/utilitarian identities too (Balmer 2011b; 2013a). Also, the Omni-temporal perspective is also of salience (Balmer et al, 2006; Urde. et. al 2007; Balmer 2011b).

From an organisational identity perspective: The notion refers to what organisational members perceive to be central, distinctive, and enduring in terms of collective heritage identity claims following the clear logic that an identifiable corporate heritage institution needs to exist in in order for organisational members to make heritage identity claims about it. As such, this builds on Albert and Whetten's (1985) delineation of organisational identity. However, the enduring nature of an organisation's identity has been questioned within the organisational identity field (Gioia, et al. 2000). Yet, the study of Balmer and Chen (2015), on the Tong Ren Tang (TRT) corporate heritage institution but taking a consumer rather than an organisational member perspective confirmed both Albert and Whetten's (1985) of "enduring" criterion and Larçon and Reitter's (1979) "stability" criterion (cited earlier) are especially germane for corporate heritage institutions. Thus, it was as if Albert and Whetten and Larçon and Reitter were articulating the core traits of heritage organisations. In addition, the perceived/claimed stability and enduring notions conform to the explication of corporate heritage identity by Balmer (2011b, 2013) and Burghausen and Balmer (2014a; 2015) and in particular, to Balmer's (2013) corporate identity criteria - especially that of the institutional trait consistency/constancy criterion (see: Balmer and Chen, 2015).

From an organisational memory perspective: These claimed heritage traits are predicated on the organisational memories/reminiscences that organisational members share, which constitute the organisation's past for them and that manifest in multiple ways including cognitions, practices and artefacts). Yet they are also qualitatively different in that not all organisational memories/reminiscences are necessarily valorised into heritage. More importantly, organisational memories - appropriated and valorised into heritage identity traits - do not only constitute the past in the present for organisational members but meaningfully extended the past into the present but also into the future (this latter aspect is, of course, informed by the corporate heritage perspective).

\section{Organisational Heritage Identification}

The second school-of-thought refers to the identification/self-categorisation of organisational members with and through their membership of a corporate heritage entity. This second perspective suggests that the process of the selective appropriation and valorisation (the attribution of value) of the organisational past into organisational heritage by organisational members may impact on organisational members' self-defining identity. This is because organisational members (employees and managers) not only define themselves as individuals in the present context of their work organisation and vis-à-vis other organisations but concurrently in relation to the past and the future. As such, the perceived 'oneness' of an individual with the organisation as a group of people is predicated also on an 'oneness' with past and prospective future generations. This expanded identification across multiple generations (i.e., 'Omni-temporal' or 'transtemporal') - consistent with the multi-generational precept discussed within corporate heritage scholarship (Balmer 2011b, 2013a) - may constitute a particular form of organisational identification, viz. organisational heritage identification.

The logic for this perspective relates to the three literatures in the following way.

From a corporate identity perspective: the very existence of a corporate heritage is a pre-requisite for this second school-ofthought on organisational heritage which focuses on organisational members' identification with a corporate heritage 
identity. Without corporate identity, organisational heritage identification cannot emerge. The notion of organisational heritage identification was mentioned as potential area of interest in research undertaken by Balmer and Chen (2015). As they noted:

“...the extant concepts of organisational identity, organisational identification can be adapted within a corporate heritage context viz: organisational heritage/ organisational heritage identities and organisational heritage identification". (Balmer and Chen 2015, p.X).

The Omni-temporal dimension of corporate heritage materially informs our characterisation of organisational heritage in this second school-of-thought (Balmer et al, 2006; Urde. et. al 2007; Balmer 2011b).. Also, the notion of institutional role identities/augmented role identities is also relevant here since corporate heritage institutions are imbued with both normative/formal "corporate" identities but also societial/utilitarian identities too (Balmer 2011b; 2013a) and, as such, organisational members can identify with both of the above. Of course, as corporate marketing scholars are all-too-aware, the issue of employee identification has long been recognised to be of salience. For instance, Tagiuri (1982) noted that employees asses a firm's identity traits in terms of whether they meet an employee's needs, including solving important life-tasks. One important aspect of this school-of-thought is the notion that organisations constitute a locus and a context for identification and/or "sense-making". For instance, it was stated that corporate heritage identities are powerful because they are meaningful in giving and bequeathing identity and in nurturing identification. This was dependant on bilateral trust between a corporate heritage organisation and stakeholders (including organisational members) which required authenticity on the part of the institution and affinity on the part of stakeholders/organisational members (Balmer, 2011b).

From an organisational identity perspective: This second school of thought has its origins in social identity/selfcategorisation theory (Tajfel, 1982; Turner, 1975), which later informed the notion of organisational identification among management scholars (Ashford and Mael 1989). In terms of our perspective, organisational heritage as organisational heritage identification can be conceptualised in terms of a practice/process. This understanding is consistent with organisational identification (Ashford and Mael, 1989) in so far as organisational members come to identify themselves with a corporate heritage identity. Thus, account is taken of the fit, relevance and favourability of certain heritage identity traits for them and the organisation (as a group) in terms of defining the self. As such, it represents an interpretive activity of sensemaking (the corollary of sense-giving detailed above) by organisational members. Such sense-making is Omni-temporal in character in that it is at once retrospective and prospective and which establishes a specific Omni-temporal continuity between past, present and future. In terms of the selective appropriation and valorisation of the organisational past by organisational members as a means of defining the self this can be explained in terms of the process of turning some aspect of an organisation's past (ideational or material) into heritage so that that aspect becomes/remains meaningfully relevant for contemporary concerns and purposes but is concurrently perceived as worth to be maintained and nurtured for future generations.

From an organisational memory perspective: the process of valorisation of the past into heritage is predicated on processes of remembering and forgetting the organisational past by organisational members as they selectively appropriate certain aspects while discarding others. As such, the organisational memory standpoint of perceiving it as a collective and symbolic phenomenon is of relevance here.

\section{Organisational cultural identification}

The importance of the organisational heritage is apparent in terms of Balmer's (2013) articulation of the culture dimension of his corporate heritage marketing mix where a corporate heritage culture was defined as:

"The perennial sense of who we are on the part of successive generations of organisational members and, where applicable, owners (family owned businesses for example)" (Balmer 2013, p.318)

This is a significant, additional, perspective vis-à-vis organisational identification. This perspective marries the insights of organisational behaviourists Whetten and Godfrey (1998) but also the perspective of Balmer (2008) from a corporate marketing perspective in relation to his identity based view of the firm notion. Both viewpoints note the existence and significance of identification with a corporate culture. Arguably, too, the appropriation, valorisation and subsequent identification can be a characteristic of a corporate heritage culture as well as with a corporate heritage entity per se. 